\title{
Does Ibuprofen Worsen COVID-19?
}

\author{
Nicholas Moore ${ }^{1}$ (1) $\cdot$ Bruce Carleton $^{2} \cdot$ Patrick Blin $^{1} \cdot$ Pauline Bosco-Levy $^{1} \cdot$ Cecile Droz $^{1}$
}

Published online: 11 June 2020

(c) Springer Nature Switzerland AG 2020

In March 2020, the French authorities warned against the use of ibuprofen in patients with coronavirus disease 2019 (COVID-19) symptoms [1,2]. This advice was based on unconfirmed anecdotal reports that severe COVID-19 cases had been exposed to ibuprofen [3] and on the theories described below. In particular, concern surrounded a possible increased expression of the angiotensin-converting enzyme (ACE)-2 receptor [4], which is the target for cell penetration of severe acute respiratory syndrome coronavirus 2 (SARS-CoV-2) [5]. This was reported on by the $B M J$ [6-8] and resulted in an $80 \%$ decrease in the use of ibuprofen in France [9]. The European Medicines Agency urged prudence [10]. The World Health Organization initially recommended not using ibuprofen, then relented [11]. Similarly, the Medicines and Healthcare products Regulatory Agency in the UK reversed their initial recommendation to avoid nonsteroidal anti-inflammatory drugs (NSAIDs) [12], concluding "There is currently no evidence that the acute use of NSAIDs causes an increased risk of developing COVID-19 or of developing a more severe COVID-19 disease." The Italian Society of Pharmacology released a statement along the same lines [13]. Among all NSAIDs, ibuprofen was probably targeted because it is widely used and available over the counter (OTC), unlike other NSAIDs in France.

The bases for the French Ministry's decision appear to be as follows:

1. A suggestion that ibuprofen might upregulate ACE-2, thereby increasing the entrance of COVID-19 into the cells $[4,14]$. In a single study in streptozotocin-induced diabetic rats, ibuprofen decreased cardiac fibrosis [15]. We found no corresponding human study [16]. An

Nicholas Moore

Nicholas.moore@u-bordeaux.fr

1 Bordeaux PharmacoEpi, INSEMR CIC 1401, Universityd of Bordeaux, 146 rue Leo Saignat, 33076 Bordeaux, France

2 Department of Pediatrics, Faculty of Medicine, University of British Columbia, Vancouver, Canada increased risk of severe COVID-19 was noted in patients with hypertension or diabetes, and a possible role of ACE inhibitors (ACEIs) or angiotensin receptor blockers (ARBs), and thiazolidinedione antidiabetic drugs, which also upregulate ACE-2, was suggested [4].

2. An analogy with bacterial soft-tissue infections, where patients receiving NSAIDs had more severe infections because of the immune-depressive actions of NSAIDs or belated treatment because of initial symptom suppression $[6,17-19]$.

3. Fever is a natural response to viral infection and reduces viral activity: antipyretic activity would reduce natural defenses against viruses.

However, the relevance of these assertions is unclear. The relevance of the upregulation of ACE- 2 in the occurrence or severity of COVID-19 is disputed [20,21]. Several studies found no impact from previous use of ACEIs or ARBs on COVID-19 frequency [22-24] and recommended against stopping ACEIs or ARBs [21, 25, 26]. In fact, ACE-2 upregulation might also limit the severity of COVID-19 infection $[25,27]$, and studies reported a lower death rate in patients using ACEIs [24].

The finding that ibuprofen might upregulate ACE- 2 came from a single animal experiment in myocardial fibrosis in streptozotocin-induced diabetic rats [15]. If confirmed in humans, this upregulation would be related to chronic use of NSAIDs before the infection, in which case the upregulation might increase the risk of SARS-CoV2 penetration into the cells, causing COVID- 19 .

However, chronic use of NSAIDs was not associated with COVID-19 [22]. Chronic use of NSAIDs might even be protective against both the occurrence and the severity of COVID-19. A study of previous exposure to a range of medicines was conducted in 12,808 patients tested for SARS-COV-2 in five Massachusetts (USA) hospitals. In total, 2271 of these patients tested positive; 707 were admitted to hospital and 213 received artificial ventilation. Exposure to ibuprofen, naproxen, oseltamivir, or atenolol was associated with a lower risk of hospital admission, 
and ibuprofen was also associated with a lower, albeit nonsignificant for lack of power, risk of artificial ventilation (odds ratio 0.47 [95\% confidence interval 0.14-1.05]) [28].

In the acute use of ibuprofen or other NSAIDs for the symptomatic treatment of COVID-19, as discouraged by the French authorities, the hypothesis of an increased risk of infection would not apply: these patients are already infected. In addition, the timeframe of upregulation is unknown, so whether any upregulation exists at that point is uncertain. The effects of any upregulation after infection are also unknown. If ACE-2 upregulation also effectively mitigates COVID-19 symptoms, might using ibuprofen actually be beneficial?

An anti-inflammatory effect masking the early symptoms of infection resulting in belated antibiotic or other treatment is not applicable here: no treatment for the virus exists to be affected by masking symptoms. The disease itself is rather unusual in that even relatively severe pulmonary infection commonly remains mostly asymptomatic until sudden decompensation apparently related to a cytokine storm, an excessive immune reaction. In this context, immune suppression or reduction might in fact be beneficial [28], as has also been suggested for the use of corticosteroids $[29,30]$.

An antipyretic effect increasing the risk or severity of infection would apply equally to all antipyretic agents, including paracetamol. None of the reports about the use of ibuprofen in COVID-19 mention the use or not of paracetamol before or in the early stages of infection, whereas this use is widespread [31-33].

These findings raise the following points:

- An indication bias may exist: more severe cases with more symptoms and higher fever might not respond well to the first-line antipyretic paracetamol, so ibuprofen would then be used (channeling). The same has been described with soft-tissue infection [34]. This may be compounded by a reporting notoriety bias [35], where only cases exposed to ibuprofen are reported.

- The reality of an increased risk of severe pneumonia in patients chronically on drugs that upregulate ACE-2, such as NSAIDs, ACEIs, or ARBs, has not been shown; in fact, upregulating ACE-2 might also have beneficial effects $[20,21,25]$. Prior use of ACEIs either did not change or reduced the risk of death in patients with COVID-19 [22].

- In a study of associations between exposure to ACEIs or ARBs and influenza, the risk of influenza was lower with ACEIs or ARBs, and this protection increased with the duration of use [36]. Preexisting diseases that may also be worsened by long-term NSAIDs, such as hypertension or heart failure, seem to increase the risk of mortality in COVID-19 [22, 37, 38].
A public health decision based on a few anecdotal reports and irrelevant experimental data may have deprived patients of a drug effective at controlling pain and fever. Encouraging the use of paracetamol while discouraging the use of ibuprofen might induce patients to use higher doses of paracetamol rather than adding ibuprofen for symptom control, increasing the risk of hepatic injury [31,39-41], which might also be increased by COVID-19-related alterations of liver function [42-44].

At this point, there exist no scientific data to support an increased risk of SARS-CoV-2 infection or COVID-19 severity with ibuprofen. As for chloroquine [45], it is certainly time for a properly conducted study of the potential risks and benefits of ibuprofen in COVID-19 [46, 47].

A prospective randomized trial is probably not feasible given the current circumstances [48]. Studies of claims databases or medical records could capture previous chronic use of medicines but probably not the use of OTC drugs such as ibuprofen or paracetamol for symptom relief in the early stages of COVID-19. It might be appropriate to attempt a study (e.g., case-control study such as NCT04383899) in a cohort of patients newly diagnosed with COVID-19 to explore questions related to the early treatment of COVID19 symptoms.

Data sharing Data sharing is not applicable to this article as no datasets were generated or analyzed during the current study.

\section{Compliance with ethical standards}

Funding No sources of funding were used to prepare this manuscript.

Conflict of interest Nicholas Moore has provided expert advice to pharmaceutical companies and regulators concerning risks associated with low-dose NSAIDs and other analgesics over the last $\geq 30$ years. Bruce Carleton, Patrick Blin, Pauline Bosco-Levy, and Cecile Droz have no conflicts of interest that are directly relevant to the content of this manuscript.

\section{References}

1. Le ministre de la santé déconseille l'ibuprofène contre le coronavirus. Le Monda. 2020 March 14. https://www.lemonde.fr/socie te/article/2020/03/14/face-au-coronavirus-le-ministre-de-la-sante -recommande-de-ne-pas-prendre-d-ibuprofene_6033095_3224. html.

2. DGS-urgent. Liste des messages d'alertes. https://dgs-urgent.sante .gouv.fr/dgsurgent/inter/detailsMessageBuilder.do;jsessionid $=21 \mathrm{ECACBF} 8 \mathrm{~B} 1 \mathrm{ECE} 6 \mathrm{C} 542 \mathrm{~B} 9126 \mathrm{E} 7 \mathrm{~A} 8215 \mathrm{~F}$.du-dgsurgentc $2 ? \mathrm{id}=30500 \& \mathrm{cmd}=$ visualiserMessage.

3. Bosredon M. Video: Coronavirus à Bordeaux: Au cœur de l'unité Covid-19 du service réanimation du CHU Pellegrin. https:// www.20minutes.fr/societe/2742271-20200317-coronavirus-borde aux-ur-unite-covid-19-service-reanimation-chu-pellegrin. 
4. Fang L, Karakiulakis G, Roth M. Are patients with hypertension and diabetes mellitus at increased risk for COVID-19 infection? Lancet Respir Med. 2020;8(4):e21. https://doi.org/10.1016/ S2213-2600(20)30116-8.

5. Hoffmann M, Kleine-Weber H, Schroeder S, Kruger N, Herrler $\mathrm{T}$, Erichsen S, et al. SARS-CoV-2 cell entry depends on ACE2 and TMPRSS2 and is blocked by a clinically proven protease inhibitor. Cell. 2020;181(2):271-80.

6. Little P. Non-steroidal anti-inflammatory drugs and covid-19. BMJ. 2020;368:m1185.

7. Day M. Covid-19: ibuprofen should not be used for managing symptoms, say doctors and scientists. BMJ. 2020;368:m1086.

8. Day M. Covid-19: European drugs agency to review safety of ibuprofen. BMJ. 2020;368:m1168.

9. Agence nationale de securite du medicament et des produits de sante. Usage des médicaments en ville durant l'épidémie de Covid-19: point de situation après cinq semaines de confinement-Point d'information. https://www.ansm.sante.fr/S-infor mer/Points-d-information-Points-d-information/Usage-desmedicaments-en-ville-durant-1-epidemie-de-Covid-19-point -de-situation-apres-cinq-semaines-de-confinement-Point-d-infor mation.

10. European Medicines Agency. EMA gives advice on the use of non-steroidal anti-inflammatories for COVID-19. London: EMA; 2020 March 18. https://www.ema.europa.eu/en/news/ema-gives -advice-use-non-steroidal-anti-inflammatories-covid-19.

11. Updated: WHO Now Doesn't Recommend Avoiding Ibuprofen For COVID-19 Symptoms. https://www.sciencealert.com/whorecommends-to-avoid-taking-ibuprofen-for-covid-19-symptoms.

12. Torjesen I. Covid-19: ibuprofen can be used for symptoms, says UK agency, but reasons for change in advice are unclear. BMJ. 2020;369:m1555.

13. Capuano A, Scaglione F, Berrino L, Del Re M, Bernardini R, Chiamulera $\mathrm{C}$, et al. Official statement of the section of Clinical Pharmacology of Italian Society of Pharmacology on Nonsteroidal anti-inflammatory drugs (NSAIDs) and the increased risk of complications during infections with commentary. Pharmadvances 2020; 2(1):6-10. https://www.pharmadvances.com/ official-statement-of-the-section-of-clinical-pharmacology-of-itali an-society-of-pharmacology-on-non-steroidal-anti-inflammato ry-drugs-nsaids-and-the-increased-risk-of-complications-durin g-infection-2/.

14. Wan Y, Shang J, Graham R, Baric RS, Li F. Receptor recognition by the novel coronavirus from Wuhan: an analysis based on decade-long structural studies of SARS coronavirus. J Virol. 2020;94(7).

15. Qiao W, Wang C, Chen B, Zhang F, Liu Y, Lu Q, et al. Ibuprofen attenuates cardiac fibrosis in streptozotocin-induced diabetic rats. Cardiology. 2015;131(2):97-106.

16. Freund A. Coronavirus confusion about safety of ibuprofen. 2020 March 20. https://www.dw.com/en/coronavirus-confusion-about -safety-of-ibuprofen/a-52824043.

17. Little P, Moore M, Kelly J, Williamson I, Leydon G, McDermott $\mathrm{L}$, et al. Ibuprofen, paracetamol, and steam for patients with respiratory tract infections in primary care: pragmatic randomised factorial trial. BMJ. 2013;347:f6041.

18. Voiriot G, Philippot Q, Elabbadi A, Elbim C, Chalumeau M, Fartoukh M. Risks related to the use of non-steroidal anti-inflammatory drugs in community-acquired pneumonia in adult and pediatric patients. J Clin Med. 2019;8(6).

19. Basille D, Thomsen RW, Madsen M, Duhaut P, Andrejak C, Jounieaux $\mathrm{V}$, et al. Nonsteroidal antiinflammatory drug use and clinical outcomes of community-acquired pneumonia. Am J Respir Crit Care Med. 2018;198(1):128-31.

20. Kuster GM, Pfister O, Burkard T, Zhou Q, Twerenbold R, Haaf $\mathrm{P}$, et al. SARS-CoV2: should inhibitors of the renin-angiotensin system be withdrawn in patients with COVID-19? Eur Heart J. 2020;41(19):1801-3.

21. Trifiro G, Crisafulli S, Ando G, Racagni G, Drago F, Italian Society of Pharmacology. Should patients receiving ACE inhibitors or angiotensin receptor blockers be switched to other antihypertensive drugs to prevent or improve prognosis of novel coronavirus disease 2019 (COVID-19)? Drug Saf. 2020;43(6):507-509.

22. Mancia G, Rea F, Ludergnani M, Apolone G, Corrao G. Reninangiotensin-aldosterone system blockers and the risk of Covid-19. N Engl J Med. 2020. https://doi.org/10.1056/NEJMoa2006923.

23. Reynolds HR, Adhikari S, Pulgarin C, Troxel AB, Iturrate E, Johnson $\mathrm{SB}$, et al. Renin-angiotensin-aldosterone system inhibitors and risk of Covid-19. N Engl J Med. 2020. https://doi.org/10.1056/ NEJMoa2008975.

24. Ip A, Parikh K, Parrillo JE, Mathura S, Hansen E, Sawczuk IS, et al. Hypertension and renin-angiotensin-aldosterone system inhibitors in patients with Covid-19. medRxiv. 2020:2020.04.24.20077388.

25. Vaduganathan M, Vardeny O, Michel T, McMurray JJV, Pfeffer MA, Solomon SD. Renin-angiotensin-aldosterone system inhibitors in patients with Covid-19. N Engl J Med. 2020;382(17):16539. https://doi.org/10.1056/NEJMsr2005760.

26. Jarcho JA, Ingelfinger JR, Hamel MB, D'Agostino RB Sr, Harrington DP. Inhibitors of the renin-angiotensin-aldosterone system and Covid-19. N Engl J Med. 2020. https://doi.org/10.1056/ NEJMe2012924.

27. Zolk O, Hafner S, Schmidt CQ, German Society for Experimental, and Clinical Pharmacology, and Toxicology. COVID-19 pandemic and therapy with ibuprofen or renin-angiotensin system blockers: no need for interruptions or changes in ongoing chronic treatments. Naunyn Schmiedebergs Arch Pharmacol. 2020. https:// doi.org/10.1007/s00210-020-01890-6.

28. Castro VM, Ross RA, McBride SM, Perlis RH. Identifying common pharmacotherapies associated with reduced COVID19 morbidity using electronic health records. medRxiv. 2020:2020.04.11.20061994.

29. Russell B, Moss C, George G, Santaolalla A, Cope A, Papa S, et al. Associations between immune-suppressive and stimulating drugs and novel COVID-19-a systematic review of current evidence. Ecancermedicalscience. 2020;14:1022.

30. Russell B, Moss C, Rigg A, Van Hemelrijck M. COVID-19 and treatment with NSAIDs and corticosteroids: should we be limiting their use in the clinical setting? Ecancermedicalscience. 2020;14:1023.

31. Moore N, Duret S, Grolleau A, Lassalle R, Barbet V, Duong M, et al. Previous drug exposure in patients hospitalised for acute liver injury: a case-population study in the French National Healthcare Data System. Drug Saf. 2019;42(4):559-72.

32. Duong M, Gulmez SE, Salvo F, Abouelfath A, Lassalle R, Droz $\mathrm{C}$, et al. Usage patterns of paracetamol in France. Br J Clin Pharmacol. 2016;82(2):498-503.

33. Duong M, Salvo F, Pariente A, Abouelfath A, Lassalle R, Droz C, et al. Usage patterns of 'over-the-counter' vs prescription-strength nonsteroidal anti-inflammatory drugs in France. Br J Clin Pharmacol. 2014;77(5):887-95.

34. Lesko SM, O’Brien KL, Schwartz B, Vezina R, Mitchell AA. Invasive group A streptococcal infection and nonsteroidal antiinflammatory drug use among children with primary varicella. Pediatrics. 2001;107(5):1108-15.

35. Pariente A, Gregoire F, Fourrier-Reglat A, Haramburu F, Moore $\mathrm{N}$. Impact of safety alerts on measures of disproportionality in spontaneous reporting databases: the notoriety bias. Drug Saf. 2007;30(10):891-8.

36. Chung SC, Providencia R, Sofat R. Association between angiotensin blockade and incidence of influenza in the United Kingdom. N Engl J Med. 2020. https://doi.org/10.1056/NEJMc2005396. 
37. Yang X, Yu Y, Xu J, Shu H, Xia J, Liu H, et al. Clinical course and outcomes of critically ill patients with SARS-CoV-2 pneumonia in Wuhan, China: a single-centered, retrospective, observational study. Lancet Respir Med. 2020;8(5):475-81. https://doi. org/10.1016/S2213-2600(20)30079-5.

38. Zhang JJ, Dong X, Cao YY, Yuan YD, Yang YB, Yan YQ, et al. Clinical characteristics of 140 patients infected with SARS-CoV-2 in Wuhan. China Allergy. 2020. https://doi.org/10.1111/all.14238

39. Gulmez SE, Larrey D, Pageaux GP, Bernuau J, Bissoli F, Horsmans $\mathrm{Y}$, et al. Liver transplant associated with paracetamol overdose: results from the seven-country SALT study. Br J Clin Pharmacol. 2015;80(3):599-606.

40. Gulmez SE, Larrey D, Pageaux GP, Lignot S, Lassalle R, Jove J, et al. Transplantation for acute liver failure in patients exposed to NSAIDs or paracetamol (acetaminophen): the multinational case-population SALT study. Drug Saf. 2013;36(2):135-44.

41. Gulmez SE, Unal US, Lassalle R, Chartier A, Grolleau A, Moore $\mathrm{N}$. Risk of hospital admission for liver injury in users of NSAIDs and nonoverdose paracetamol: Preliminary results from the EPIHAM study. Pharmacoepidemiol Drug Saf. 2018;27(11):1174-81.

42. Rismanbaf A, Zarei S. Liver and kidney injuries in COVID-19 and their effects on drug therapy; a Letter to Editor. Arch Acad Emerg Med. 2020;8(1):e17.
43. Wan S, Xiang Y, Fang W, Zheng Y, Li B, Hu Y, et al. Clinical features and treatment of COVID-19 patients in Northeast Chongqing. J Med Virol. 2020. https://doi.org/10.1002/jmv.25783.

44. Zhao D, Yao F, Wang L, Zheng L, Gao Y, Ye J, et al. A comparative study on the clinical features of COVID-19 pneumonia to other pneumonias. Clin Infect Dis. 2020. https://doi.org/10.1093/ cid/ciaa247.

45. Moore N. Chloroquine for COVID-19 infection. Drug Saf. 2020;43(5):393-4.

46. Sodhi M, Etminan M. Safety of ibuprofen in patients with COVID19: causal or confounded? Chest. 2020. https://doi.org/10.1016/j. chest.2020.03.040.

47. Sridharan GK, Kotagiri R, Chandiramani VH, Mohan BP, Vegunta $\mathrm{R}$, Vegunta R, et al. COVID-19 and avoiding ibuprofen. How good is the evidence? Am J Ther. 2020. https://doi.org/10.1097/ MJT.0000000000001196.

48. Pottegard A, Kurz X, Moore N, Christiansen CF, Klungel O. Considerations for pharmacoepidemiological analyses in the SARSCoV-2 pandemic. Pharmacoepidemiol Drug Saf. 2020. https://doi. org/10.1002/pds.5029. 